\title{
Vernodalinol isolated from Struchium sparganophora (Linn) Asteraceae
}

\author{
Kasim L. S. ${ }^{1 *}$, Ukpo G. E. ${ }^{2}$ and Odukoya O. A. ${ }^{3}$ \\ ${ }^{1}$ Department of Pharmaceutical and Medicinal Chemistry, Olabisi Onabanjo University, Sagamu, Ogun State, Nigeria. \\ ${ }^{2}$ Department of Pharmaceutical and Medicinal Chemistry, University of Lagos, Lagos State, Nigeria \\ ${ }^{3}$ Department of Pharmacognosy, University of Lagos, Lagos State, Nigeria
}

Accepted 29 September, 2013

\begin{abstract}
Chemical investigation of anti-microbial and anti-fungal components of the leaves of Struchium sparganophora through the application of vacuum liquid chromatogtaphy (VLC), column liquid chromatography (CLC) and preparative thin layer chromatography (PTLC) resulted in isolation of a sesquiterpene lactone, vernodalinol. This compound was subjected to anti-fungal and cytotoxic tests. It exhibited a significant antifungal properties $(P>.05)$ at the concentrations of 12.5 to $25 \mu \mathrm{g} / \mathrm{ml}$ and cytotoxic effects against melanoma and ovarian cancer cell lines at the concentrations of $3-5 \times 10^{-3}$ $\mu \mathrm{g} / \mathrm{ml}$; the structure of this compound was determined by spectroscopic methods. This compound portend a useful chemotherapeutic agent in the treatment of fungal and cancer infections
\end{abstract}

Key words: Struchium sparganophora. Asteraceae, elemanolide lactone, vernodalinol.

\section{INTRODUCTION}

The search for natural occurring anti-infective agents for the treatment of fungal infections has led us to examine Struchium sparganophora, a culinary herb that has various medicinal uses among the traditional medicinal practitioners in western part of Nigeria.

Fungal infections are traditionally divided into two distinct classes- superficial and systemic. Some of the causative organisms of fungal infections are as follows, Candida species, Cryptococcus neoformans, Blastomyces dermatitis, Histoplasma capsulatum, Torulopsis glabrata, Coccidiodes immiti, Paracoccidiodes braziliensis, Aspergillus species, protozoa, Leishmania brazilliences, Naegleria fowleri and the agents mucomycosis. Antimycotic agents are used for the treatment of fungal infections. Initial major progress in the therapy of mycoses was made in the 1960's with the introduction of the polyene antimycotics, flucytosine and griseofulvin (Schild, 1980). Of major importance later was the development of antimycotics of the azole-type, these drugs, being wide spectrum antimycotics, are effective to a large extent against a variety of fungal infections and, therefore, have replaced many older antibiotics. But the present invention has proved to offer a better effect than the azole-type.

S. sparganophora a culinary herb used for the treatment of gonorrhea (Aka and Ekekwe, 1995), measles and as an anti-poison agent (Burkil, 1995; Hutchison and Dalziel, 1963) has afforded elemanolide lactone, vernodalinol (Figure 1) apart from vernodalin and the 10 membered sesquiterpene lactone that was previously isolated from this plant (Kasim et al., 2011a; Jakupovic et al., 1987). A number of elemanolide lactones had been previously isolated from the same genus (Kupchan et al., 1969a). We now report the isolation of anti-fungal sesquiterpene lactone (vernodalinol) mainly by VLC, CLC and PTLC, whose spectroscopic data were in conformity with vernodalinol data of Luo et al. (2011) isolated from Vernonia 
<smiles>C=CC12COC(=O)C(=C)C1C(O)C(C(=C)O)B(OC(=O)C(=C)CO)O2</smiles>

Figure 1. Vernodalinol.

Table 1. ${ }^{1} \mathrm{H}$ NMR spectra data of vernodalinol in pyridine.

\begin{tabular}{llll}
\hline Assignment & \multicolumn{2}{c}{ Chemical shift $(\delta)$} & Coupling constant $(\mathbf{H z})$ \\
\hline $\mathrm{H}-1$ & $1 \mathrm{H}$ & 5.81 & $\mathrm{dd}, \mathrm{J}=10.8,17.7$ \\
$\mathrm{H}-2$ & $1 \mathrm{H}$ & 5.22 & $\mathrm{~d}, \mathrm{~J}=10.9$ \\
& $1 \mathrm{H}$ & 5.33 & $\mathrm{~d}, \mathrm{~J}=17.5$ \\
$\mathrm{H}-5$ & $1 \mathrm{H}$ & 3.27 & $\mathrm{~d}, \mathrm{~J}=11.3$ \\
$\mathrm{H}-6$ & $1 \mathrm{H}$ & 4.56 & $\mathrm{t}, \mathrm{J}=11.2$ \\
$\mathrm{H}-7$ & $1 \mathrm{H}$ & 3.17 & $\mathrm{tt}, \mathrm{J}=3,11.0$ \\
$\mathrm{H}-8$ & $1 \mathrm{H}$ & 5.55 & $\mathrm{dt}, \mathrm{J}=4.6,10.5$ \\
$\mathrm{H}-9$ & $1 \mathrm{H}$ & 2.27 & $\mathrm{dd}, \mathrm{J}=4.6,13.9$ \\
& $1 \mathrm{H}$ & 1.74 & $\mathrm{dd}, \mathrm{J}=10.5,13.9$ \\
$\mathrm{H}-13$ & $1 \mathrm{H}$ & 5.77 & $\mathrm{~d}, \mathrm{~J}=3$ \\
& $1 \mathrm{H}$ & 6.22 & $\mathrm{~d}, \mathrm{~J}=3$ \\
$\mathrm{H}-14$ & $1 \mathrm{H}$ & 4.37 & $\mathrm{dd}, \mathrm{J}=15,12.2$ \\
& $1 \mathrm{H}$ & 4.9 & $\mathrm{~d}, \mathrm{~J}=12.2$ \\
$\mathrm{H}-15$ & $1 \mathrm{H}$ & 5.92 & $\mathrm{br} \mathrm{s}$ \\
& $1 \mathrm{H}$ & 6.82 & $\mathrm{~d}, \mathrm{~J}=1$ \\
$\mathrm{H}-3$, & $2 \mathrm{H}$ & & br s \\
$\mathrm{H}-4$ & $1 \mathrm{H}$ & 6.33 & $\mathrm{~d}, \mathrm{~J}=1.8$ \\
& $1 \mathrm{H}$ & 6.50 & $\mathrm{~d}, \mathrm{~J}=1.8$ \\
\hline
\end{tabular}

amygdalina.

\section{MATERIALS AND METHODS}

\section{Plant material}

The leaf part of S. sparganophora was harvested from the Sagamu community in the Sagamu local government area of Nigeria. The leaf was identified and authenticated by Mr. I. K. Idewo of the Forest Research Institute of Nigeria, Ibadan, and comparison was made with Voucher specimens FHI 105358 kept at the Department of Pharmacognosy, College of Medicine, University of Lagos.

\section{Extraction and isolation}

The leaves were dried in an oven $\left(40^{\circ} \mathrm{C}\right)$ and powdered. The powdered leaves $(200 \mathrm{mg})$ was subjected to sequential solvent extraction with solvents of increasing polarity, $n$-hexane, chloroform and methanol, using a soxhlet apparatus and the extracts were concentrated under reduced pressure (Rotavapor-R, Buchi, UK) to give a yield of $34 \% \mathrm{w} / \mathrm{w}$ for chloroform extract. This was then subjected to vacuum liquid chromatography (VLC) with chloroformmethanol $(100: 0,0: 100)$. The fractions 5 to $25 \%$ methanolchloroform were merged together based on similar compounds on TLC and the chlorophyll was removed using Sephadex LH-20. The fractions containing vernodalinol was subjected to column chromatography eluting with chloroform/ methanol mixture which resulted in the isolation of vernodalinol which was further purified with preparative thin layer chromatography (PTLC).

\section{Spectroscopic analysis}

${ }^{1} \mathrm{H}$ and ${ }^{13} \mathrm{C}$ NMR spectra were recorded on NMR Spectrometer (Brucker AMX-400 instrument Japan). Infra-red spectra were recorded on a Matson Genesis series FT-IR Spectrometer by drying chloroform of the sample on $\mathrm{NaCl}$ windows.

\section{Microbiological assay}

The antifungal tests were carried out according to Drumond and Waigh (2000). Resazurin (7-hydroxy-3h-Phenoxazuzin-3-one10 oxide) (Sigma, UK) was used to make the indicator solution for the microdilution assay. This dye was purple when cells were viable and blue where cells were not viable. Two fungi were used: Candida albicans (ATCC10231) and Aspergillus niger

\section{Sample preparation}

The cell preparation was done according to Kasim et al. (2011b) method. A high concentration $(1 \mathrm{mg} / \mathrm{ml})$ of the compound was made and this was diluted as required. $100 \mu \mathrm{g} / \mathrm{ml}$ of test compound was first prepared as the stock solutions. After which a serial dilutions of concentrations of $25.0-0.0625 \times 10^{-3} \mu \mathrm{g} / \mathrm{ml}$ of the compound were prepared and used for the growth curve.

\section{In vitro cytotoxicity test}

The MTT cytotoxicity/proliferation assay (Mosman, 1983) was used to measure the toxicity of the test materials by determining the absorbance of the cells in culture. Two exposure periods of 24 and $48 \mathrm{~h}$ were chosen for determining the in vitro cytotoxicity of the test compound along with a positive control containing the cell lines and the medium, and the negative control containing the medium and the sample.

The percentage cell growth was calculated against the medium as mean of triplicate reading \pm SD. The results were stated as concentration to reduce the absorbance of treated cells by $50 \%$ with reference to the control (untreated cells) or cancer cell growth inhibition $\left(I_{50}\right)$ and the lethal dose LD values $(\mu \mathrm{g} / \mathrm{ml})$ of the compound derived from the growth curve are expressed in Table 1.

\section{RESULTS AND DISCUSSION}

Vernodalinol (1H-2-benzopyran-6-acetic acid), a colourless oil, stable at room temperature was first isolated from V. amygdalina by Luo et al. (2011) and gave the 
Table 2. ${ }^{13} \mathrm{C}$ NMR spectra data of vernodalinol in pyridine.

\begin{tabular}{lclc}
\hline Carbon & $\delta$ & Carbon & $\boldsymbol{\delta}$ \\
\hline C-1 & 141.7 & C-11 & 137.9 \\
C-2 & 117.3 & C-12 & 169.9 \\
C-3 & 164 & C-13 & 121.2 \\
C-4 & 132 & C-14 & 71.8 \\
C-5 & 47.5 & C-15 & 135.1 \\
C-6 & 79.1 & C-1' & 166.4 \\
C-7 & 51.3 & C-2' & 142 \\
C-8 & 69.8 & C-3' & 61.7 \\
C-9 & 40.0 & C-4' & 126 \\
C-10 & 42.3 & & \\
\hline
\end{tabular}

Table 3. The results of anti-fungal tests of vernodalinol showing the minimum inhibitory concentration (MIC) in $\mu \mathrm{g} / \mathrm{ml}$.

\begin{tabular}{lcc}
\hline Micro-organism & Vernodalinol & Fluconazole \\
\hline C. albican & 25 & 50 \\
A. niger & 12.5 & 50 \\
\hline
\end{tabular}

$\mathrm{P}>0.05$.

Table 4. $I C_{50}$ and $L D_{50}$ values $(\mu \mathrm{g} / \mathrm{ml})$ of vernodalinol after $48 \mathrm{~h}$ reculture without the compounds.

\begin{tabular}{lcc}
\hline \multirow{2}{*}{ Cell Line } & \multicolumn{2}{c}{ Vernodalinol } \\
\cline { 2 - 3 } & $\mathbf{I C}_{50}$ & $\mathbf{L D}_{50}$ \\
\hline HeLa & - & - \\
Melanoma & $0.003 \pm 0.000$ & $0.005 \pm 0.000$ \\
\multirow{2}{*}{ Ovarian } & 1 & 1 \\
& $0.004 \pm 0.000$ & $0.008 \pm 0.000$ \\
\hline
\end{tabular}

-, Cytopathic.

following spectroscopic results: EIMS showed prominent peaks at $\mathrm{m} / \mathrm{z}$ (rel.int.) 85 and 57 . The mass is 278 . The UV spectrum showed only end absorption $\left(\lambda^{\mathrm{MeOH}} \max \right.$ $220 \mathrm{~nm})$. The Infra red spectrum showed the characteristic bands at 3417 (hydroxyl group), 1770 (shoulder, $\delta$-lactone moiety), $1720 \mathrm{~cm}^{-1}$ carbonyl group of opened $\gamma$ lactone moeity) and $1626 \mathrm{~cm}^{-1}$ (vinyl group). The presence of one proton broad singlet at $\delta 5.92$ and a two proton broad singlet at $\delta 4.77$ in Table 1 correspond to those expected for a hydroxymethacrylate ester group which was supported by the presence in the mass spectrum peaks of m/e 57 and 85 , attributable to the fragmentation of the same branch chain. The presence of two doublets $(\mathrm{J}=3 \mathrm{~Hz})$ at $\delta 5.77$ and $\delta 6.22$ showed the protons of methylene attached to a carbonyl group, the lack of multiplet signal at carbon 11 shows the presence of free acid. The ${ }^{13} \mathrm{C}$ NMR data are tabulated in Table 2. The assignment of each peak was based on the observed multiplicity in a single-frequency off-resonance decoupled spectrum and heteronuclear multiple bond correlation (HMBC) and in accordance with Luo et al. (2011). Vernodalinol acid showed a significant inhibitory effect against $C$. albicans with MIC $25 \mu \mathrm{g} / \mathrm{ml}$ and $A$. niger MIC $12.5 \mu \mathrm{g} / \mathrm{ml}$ compared with fluconazole (Pfizer, U.K) against the two fungi $(P>0.05)$ as in Table 3. Its cytotoxic activity is also portrayed by the inhibitory activity of the growth of melanoma and ovarian cancer cell lines as shown in Table 4. This effect has also been reported about other sesquiterpine lactones having tumour inhibitory effect e.g vernolepin and vernomygdin (Kupchan et al., 1969b). This compound may portend a cure in the treatment of fungal infections and associated conditions.

\section{The results of the cytotoxic/anti-tumour test of the isolated compound}

These values were the means of three replicate infective concentrations $\left(\mathrm{IC}_{50}\right)$ that caused death for the cells. These values showed the percentage suppression in cell viability for the test sample and were determined by comparing the absorbance of the test sample with the mean control value. The $\mathrm{LD}_{50}$ is the concentration at which $50 \%$ cell death (suppression) occurred when compared with solvent control. The student t-test was used to determine whether there was any significant difference between treatments and controls and also between two cell lines.

\section{ACKNOWLEDGEMENTS}

We wish to thank Mr. I.K. Idewo of Forest Research Institute of Nigeria, Ibadan for the authentication and identification of this plant and Olabisi-Onabanjo University, Ogun State, Nigeria, who granted Mr. L.S. Kasim permission to carry out this work in the U.K. We are equally grateful to the Department of Pharmaceutical Sciences, University of Strathclyde, Glasgow for allowing us to use their facilities for this work

\section{REFERENCES}

Aka PA, Ekekwe RR (1995). Ethnopharmacology of some Asteraceae family used in Nigeria traditional medicine. Fitoterapia, 66:4.

Burkill HM (1985) not cited. The useful plants of tropical Africa. Royal Botanic Gardens, Kew. Families A-D, 2(1):479.

Drumond AJ, Waigh RD (2000). Recent research development. Phytochem. 4:143-152.

Hutchison J, Dalziel JM (1963). Flora of West Tropical Africa.Crown Agents for Overseas Governments and Administrations Millbank, London S.W.1, 2(11):345-520.

Jakupovic J, Zdero C, Boeker R, Warning U, Bohlmann F, Jones SB (1987). Cernocistifolide und andere sesquiterpinelactone aus 
Vernonia und verwandten Arten. Liesbigs Ann. Chem. pp.111-123.

Kasim LS, Ferro VA, Odukoya OA, Ukpo GE, Veronique Seidel GAI, Roger W (2011a). Antimicrobial Agents from Struchium sparganuphora (Linn) Ktze Asteraceae. J. Microbiol. Antimicrob. 3(1):13-17.

Kasim LS, Ferro VA, Odukoya OA, Ukpo GE, Veronique Seidel GAI, Roger W (2011b). Evaluation of cytotoxic and antimicrobial activities of Struchium sparganophora (Linn) Ktze Asteraceae., J. Med. Plants Res. 5(6):862-867.

Kupchan MS, Hemingway RJ, Karim A, Werner D (1969a). Tumour Inhibitors. XLVII ${ }^{\text {ia }}$. Vernodalin and Vernomydin. Two new cytotoxic sesquiterpenes lactones from Vernonia amygdalina Del. J. Org. Chem. pp. 3908-3911.

Kupchan MS, Hemingway RJ, Karim A, Werner D (1969b). Tumour Inhibitors. XLVI ${ }^{\text {ia }}$. Vernolepin a novel sesquiterpene dilactone tumour inhibitor from Vernonia hymenolepsis. A. Rich. J. Org. Chem. pp. 3903-3908.
Luo X, Jiang Y, Fronczek R, Liu C, Izevbigie EB, Lee KS (2011). Isolation and Structure determination of a sesquiterpine ;lactone (Vernodalinol) from Vernonia amygdalina extracts. J. Pharmaceut. Biol. 49(5):464-470.

Mosman T (1983). Rapid colorimetric assay for cellular growth and survival: application to proliferation and cytotoxicity assays. J. Immunol. Methods 65:5-63.

Schild HO (1980). Applied Pharmacology, $12^{\text {th }}$ edition, Churchill Livingstone, Edinburgh. pp. 34-50. 